\title{
Pengaruh Budaya Organisasi Terhadap Kinerja Pegawai BPJS Ketenagakerjaan
}

\author{
${ }^{1}$ Abdi, ${ }^{2}$ Mustafa Kamal, ${ }^{3}$ Rahayu Triana Yusti, ${ }^{4}$ Etnam Siregar \\ ${ }^{1-4}$ Program Studi Magister Manajemen, Fakultas Ekonomi, Universitas Islam Sumatera Utara
}

Article history

Received: 11 Jan 2021

Revised: 13 Feb 2021

Accepted: 02 Mar 2021

*Corresponding Author:

Abdi, Program Studi

Magister Manajemen,

Fakultas Ekonomi,

Universitas Islam Sumatera

Utara

Email:

Abdi53@gmail.com
Abstrak: Potensi setiap sumber daya manusia yang ada dalam perusahaan harus dapat dimanfaatkan dengan sebaik-baiknya sehingga mampu memberikan output optimal. Oleh karena itu, perusahaan juga dituntut untuk mampu mengidentifikasi hal-hal apa saja yang menjadi kendala atau permasalahan di dalam menjalankan kegiatan dan aktivitas ekonomi, termasuk masalah kinerja pegawainya dimana setiap perusahaan memiliki budaya organisasi. maka penulis merumuskan masalah sebagai berikut "Bagaimana pengaruh budaya organisasi terhadap kinerja pegawai BPJS Ketenagakerjaan Cabang Binjai?'Pendekatan dalam penelitian ini menggunakan metode kuantitatif deskriptif. Teknik analisis data berupa teknik analisis deskriptif hasil dari penelitiannya yaitu Budaya organisasi berpengaruh positif dan signifikan terhadap kinerja pegawai di BPJS Ketenagakerjaan Cabang Binjai dengan thitung > ttabel $(2.884>2.030)$ dan nilai koefisien regresi sebesar 0.404 atau $40.4 \%$. Budaya organisasi berpengaruh signifikan terhadap variabel kinerja pegawai di BPJS Ketenagakerjaan Cabang Binjai.

Kata Kunci : Budaya Organisasi, Kinerja Pegawai dan Sumber Daya Manusia

\section{PENDAHULUAN}

Organisasi merupakan wadah bagi indivdiu untuk mencapai tujuan, baik tujuan pribadi maupun tujuan organisasi. Individu dengan karakter tersendiri dan organisasi yang juga memiliki karakter tertentu yang saling menyesuaikan. Perkembangan di bidang ekonomi semakin hari semakin ketat dalam persaingan dan mengharuskan perusahaan untuk mengembangkan segala potensi yang ada di dalam perusahaannya untuk terus berinovasi, terutama dibidang sumber daya manusia. Potensi setiap sumber daya manusia yang ada dalam perusahaan harus dapat dimanfaatkan dengan sebaik-baiknya sehingga mampu memberikan output optimal. Oleh karena itu, perusahaan juga dituntut untuk mampu mengidentifikasi hal-hal apa saja yang menjadi kendala atau permasalahan di dalam menjalankan kegiatan dan aktivitas ekonomi, termasuk masalah kinerja pegawainya dimana setiap perusahaan memiliki budaya organisasi, karakteristik individu dan komunikasi yang berbeda pula. Menurut Sinambela (2012:5) kinerja adalah hasil kerja yang dapat dicapai oleh seseorang atau sekelompok orang dalam suatu organisasi, sesuai dengan wewenang dan tanggung jawab masing-masing, dalam rangka upaya mencapai tujuan organisasi bersangkutan secara legal, tidak melanggar hukum dan sesuai dengan moral dan etika.

Banyak faktor yang mendorong dan mempengaruhi sumber daya manusia yang dimiliki perusahaan agar bergerak kearah positif. Perlakuan terhadap tenaga manusia tentunya berbeda dengan perlakuan terhadap faktor produksi yang lainnya, karena tenaga manusia memiliki karakteristik yang berbeda-beda. Disinilah tantangan bagi perusahaan untuk mengatur berbagai macam kekhususan yang dimiliki tenaga kerja yaitu pegawai guna mencapai tujuan perusahaan. 
Budaya organisasi adalah salah satu faktor yang mempengaruhi tendensi anggota untuk tetap bersama organisasi dan menjaga loyalitasnya. Menurut Pabundu (2012:65) budaya organisasi adalah nilai dan praktik yang memiliki bersama diseluruh kelompok dalam satu perusahaan, sekurang-kurangnya dalam manajemen dan definisi antara budaya organisasi dan budaya perusahaan saling terkait karena kedua-duanya memiliki kesamaan, meskipun dalam budaya organisasi terdapat hal-hal khusus sebagai gaya manajemen, sistem manajemen, dan sebagainya, namun semuanya tetap dalam rangkaian budaya organisasi.

Menurut Fahmi (2014: 110) budaya organisasi membentuk nilai dan standar yang menuntun perilaku organisasi, kondisi tersebut dapat menentukan arah dari seluruh tujuan perusahaan. Sedangkan menurut menurut Robbins dan Timothy (2014:289) mengemukakan bahwa budaya organisasi adalah suatu persepsi bersama yag dianut oleh anggota-anggota orgaisasi itu. Budaya organisasi merupakan nilai-nilai bersama dan kepercayaan yang diberikan oleh anggota pada organisasi yang kemudian menghasilkan aturan-aturan berperilaku dalam keseharian berorganisasi. Suatu budaya organisasi yang kuat memperlihatkan kesepakatan yang tinggi di kalangan anggota yang dipegang teguh dan disepakati bersama. Budaya organisasi pada BPJS Ketenagakerjaan Cabang Binjai sebelumnya terkesan lebih terorganisir dengan baik, segala peraturan yang ada dipatuhi dan ditakuti oleh para pegawai. Kondisi organisasi yang ada saat ini terkesan kaku dan menjadi momok bagi para pegawai, budaya organisasi yang demikian dirasa tidak efektif oleh pimpinan BPJS Ketenagakerjaan Cabang Binjai.

Budaya kerja yang santai dapat membuat pegawai merasa nyaman dalam bekerja. Kenyamanan dalam bekerja dapat meningkatkan kinerja seorang pegawai. Kenyamanan dalam bekerja juga dapat meningkatkan semangat dan keagresifan dalam bekerja. Kuat lemahnya budaya suatu organisasi sangat bergantung pada bagaimana anggota mengaplikasikannya pada kehidupan berorganisasi dalam perusahaan. Budaya organisasi yang baik diharapkan mampu memberikan kenyamanan anggota atau karyawan dalam bekerja dan mampu memberikan peningkatan kinerja yang optimal, sehingga pegawai mampu memenuhi ekspetasi yang diharapkan oleh perusahaan. Proses komunikasi yang ada dalam BPJS Ketenagakerjaan Cabang Binjai berdasar pada beberapa jenis komunikasi organisasi, komunikasi vertikal dari atas kebawah dalam pemberian memo maupun instruksi kerja dari atasan ke bawahan mereka masing-masing, terkadang memo ataupun instruksi kerja tersebut diberikan secara langsung oleh pimpinan. Untuk komunikasi dari bawah keatas dalam bentuk kritikan maupun umpan balik secara langsung maupun secara tidak langsung.

Kritikan tersebut dapat diketahui dari kuesioner yang akan diberikan oleh perusahaan. Selain kuisioner biasanya juga didapatkan dari percakapan yang dilakukan antar para pegawai. Dalam hubungan horizontal antara pegawai yang satu dengan yang lain biasanya melalui berbicara langsung sesuai dengan kebutuhan mereka masing-masing. Proses komunikasi yang ada dalam perusahaan selalu cepat, dalam arti kata informasi yang ada bisa berubah dan dapat tersosialisasikan secara tepat pada pihak yang diperlukan. Informasi tersebut selalu dapat tersosialisasikan dengan baik karena adanya papan pengumuman pada setiap perusahaan serta adanya pemberitahuan secara langsung tentang pengumuman baik yang berhubungan dengan perusahaan maupun antar pribadi sesama pegawai. Berdasarkan uraian diatas, maka dilakukan suatu penelitian dengan judul "Pengaruh Budaya Organisasi Terhadap Kinerja Pegawai Di BPJS Ketenagakerjaan Cabang Binjai”. 


\section{METODE PENELITIAN}

Pendekatan dalam penelitian ini menggunakan metode kuantitatif deskriptif. Teknik analisis data berupa teknik analisis deskriptif. Lokasi penelitian dilakukan di BPJS Ketenagakerjaan Cabang Binjai, berlamat di Jl. Soekarno- Hatta No. 262, Km.19,5 Tunggurono, Kec. Binjai Timur, Kota Binjai, Sumatera Utara 20351. Yang menjadi objek penelitian ini adalah budaya organisasi sebagai variabel $\mathrm{X}$ dan kinerja pegawai sebagai variabel Y.

\section{HASIL DAN PEMBAHASAN}

\section{Analisis Data}

\section{Identitas Responden}

Kuesioner yang disebar ke responden atau pegawai BPJS Ketenagakerjaan Cabang Binjai berjumlah 35 orang. Berikut peneliti akan mendeskripsikan identitas responden berdasarkan jenis kelamin dan unit kerja responden.

\section{a. Identitas Responden Berdasarkan Jenis Kelamin}

Tabel 1. Identitas Responden Berdasarkan Jenis Kelamin

\begin{tabular}{cllcc}
\hline No & & Jenis Kelamin & Jumlah & Persentase (\%) \\
\hline 1 & Laki-laki & & 18 & $51,4 \%$ \\
2 & Perempuan & 17 & $48,6 \%$ \\
& & Total & $\mathbf{3 5}$ & $\mathbf{1 0 0 \%}$
\end{tabular}

Sumber: BPJS Ketenagakerjaan Cabang Binjai 2020

Berdasarkan Tabel 1 di atas, bahwa responden dengan jenis kelamin laki-laki berjumlah 18 orang $(51,4 \%)$ dan responden perempuan berjumlah 17 orang $(48,6 \%)$.

\section{b. Identitas Responden Berdasarkan Unit Kerja}

Tabel 2. Identitas Responden Berdasarkan Unit Kerja

\begin{tabular}{clcc}
\hline No & \multicolumn{1}{c}{ Bagian/Unit Kerja } & Jumlah & Persentase \\
\hline 1 & Bagian Kepesertaan & 9 & $26 \%$ \\
2 & Bagian Pelayanan & 5 & $14 \%$ \\
3 & Bagian Keuangan & 3 & $9 \%$ \\
4 & Bagian Umum dan SDM & 5 & $14 \%$ \\
5 & KCP & 4 & $11 \%$ \\
6 & Bagian Pengawasan & 3 & $9 \%$ \\
7 & Bagian Teknologi Informatika & 2 & $6 \%$ \\
8 & Office Support $\quad$ Total & 4 & $11 \%$ \\
& & $\mathbf{3 5}$ & $\mathbf{1 0 0 \%}$
\end{tabular}

Sumber: BPJS Ketenagakerjaan Cabang Binjai 2020

\section{Pernyataan Responden}

\section{Pernyataan Responden Atas Budaya Organisasi $\left(\mathbf{X}_{1}\right)$}

Penjelasan responden atas indikator-indikator variabel budaya organisasi di BPJS Ketenagakerjaan Cabang Binjai disajikan pada Tabel 3 berikut ini: 
Tabel 3. Penjelasan Responden Atas Variabel Budaya Organisasi (X)

\begin{tabular}{|c|c|c|c|c|c|c|c|c|c|c|c|c|}
\hline \multirow{3}{*}{ No } & \multicolumn{12}{|c|}{ ALTERNATIF JAWABAN } \\
\hline & \multicolumn{2}{|r|}{ SS } & \multicolumn{2}{|r|}{$\mathbf{S}$} & \multicolumn{2}{|c|}{ KS } & \multicolumn{2}{|c|}{ TS } & \multicolumn{2}{|c|}{ STS } & \multicolumn{2}{|c|}{ Jumlah } \\
\hline & $\mathbf{F}$ & $\%$ & $\mathbf{F}$ & $\%$ & $\mathbf{F}$ & $\%$ & $\mathbf{F}$ & $\%$ & $\mathbf{F}$ & $\%$ & $\mathbf{F}$ & $\%$ \\
\hline 1 & 17 & $48,6 \%$ & 14 & $40,0 \%$ & 4 & $11,4 \%$ & 0 & $0,0 \%$ & 0 & $0,0 \%$ & 35 & $100,0 \%$ \\
\hline 2 & 15 & $42,9 \%$ & 16 & $45,7 \%$ & 4 & $11,4 \%$ & 0 & $0,0 \%$ & 0 & $0,0 \%$ & 35 & $100,0 \%$ \\
\hline 3 & 12 & $34,3 \%$ & 19 & $54,3 \%$ & 4 & $11,4 \%$ & 0 & $0,0 \%$ & 0 & $0,0 \%$ & 35 & $100,0 \%$ \\
\hline 4 & 6 & $17,1 \%$ & 25 & $71,4 \%$ & 4 & $11,4 \%$ & 0 & $0,0 \%$ & 0 & $0,0 \%$ & 35 & $100,0 \%$ \\
\hline 5 & 15 & $42,9 \%$ & 14 & $40,0 \%$ & 6 & $17,1 \%$ & 0 & $0,0 \%$ & 0 & $0,0 \%$ & 35 & $100,0 \%$ \\
\hline 6 & 15 & $42,9 \%$ & 16 & $45,7 \%$ & 4 & $11,4 \%$ & 0 & $0,0 \%$ & 0 & $0,0 \%$ & 35 & $100,0 \%$ \\
\hline Rata2 & 13 & $38,1 \%$ & 17 & $49,5 \%$ & 4 & $12,4 \%$ & 0 & $0,0 \%$ & 0 & $0,0 \%$ & 35 & $100,0 \%$ \\
\hline
\end{tabular}

Sumber: Hasil Penelitian 2020

Dari Tabel 3 di atas dapat dijelaskan bahwa:

1) Jawaban responden pertanyaan No.1: Saya selalu melakukan penghayatan terhadap tujuan pelaksanaan tugas. Responden yang menjawab sangat setuju sebesar $48,6 \%$, setuju sebesar $40,0 \%$, kurang setuju sebesar $11,4 \%$

2) Jawaban responden pertanyaan No. 2: Saya selalu berusaha tepat waktu dalam melakukan tugas-tugas administrasi dan pelayanan. Responden yang menjawab sangat setuju $42,9 \%$, setuju sebesar $45,7 \%$ dan kurang setuju sebesar $11,4 \%$.

3) Jawaban responden pertanyaan No. 3: Saya selalu berusaha terhadap perbaikan mutu administrasi dan pelayanan. Responden yang menjawab sangat setuju sebesar 34,3\%, setuju sebesar 54,3\%, dan kurang setuju sebesar $11,4 \%$.

4) Jawaban responden pertanyaan No. 4: Saya selalu senang dalam melakukan tugas administrasi dan pelayanan. Responden yang menjawab sangat setuju sebesar $17,1 \%$, yang menjawab setuju sebesar $71,4 \%$ dan yang menjawab kurang setuju sebesar $11,4 \%$.

5) Jawaban responden pertanyaan No. 5: Saya selalu berusaha menciptakan suasana kerja (administrasi dan pelayanan) yang kondusif. Responden yang menjawab sangat setuju sebesar $42,9 \%$, responden yang menjawab setuju sebesar $40,0 \%$ dan yang menjawab kurang setuju sebesar $17,1 \%$.

6) Jawaban responden pertanyaan No. 6: Saya selalu berusaha loyal terhadap pimpinan perusahaan. Responden yang menjawab sangat setuju sebesar 42,9\%, responden yang menjawab setuju sebesar 45,7\% dan yang menjawab kurang setuju sebesar 11,4\%.

Secara rata-rata dapat dilihat bahwa yang terbesar jawaban responden adalah 49,5\% menyatakan setuju. Dengan demikian dapat diketahui bahwa budaya organisasi di BPJS Ketenagakerjaan Cabang Binjai adalah baik, sesuai dengan jawaban sebagian besar responden. 


\section{Pernyataan Responden Atas Kinerja Pegawai (Y)}

Penjelasan responden atas indikator-indikator variabel kinerja pegawai (Y) di BPJS Ketenagakerjaan Cabang Binjai, disajikan pada Tabel 4 berikut ini:

Tabel 4. Penjelasan Responden Atas Variabel Kinerja (Y)

\begin{tabular}{|c|c|c|c|c|c|c|c|c|c|c|c|c|}
\hline \multirow{3}{*}{ No } & \multicolumn{12}{|c|}{ ALTERNATIF JAWABAN } \\
\hline & \multicolumn{2}{|c|}{ SS } & \multicolumn{2}{|r|}{$\mathbf{S}$} & \multicolumn{2}{|c|}{ KS } & \multicolumn{2}{|c|}{ TS } & \multicolumn{2}{|c|}{ STS } & \multicolumn{2}{|c|}{ Jumlah } \\
\hline & $\mathbf{F}$ & $\%$ & $\mathbf{F}$ & $\%$ & $\mathbf{F}$ & $\%$ & $\mathbf{F}$ & $\%$ & $\mathbf{F}$ & $\%$ & $\mathbf{F}$ & $\%$ \\
\hline 1 & 14 & $40,0 \%$ & 21 & $60,0 \%$ & 0 & $0,0 \%$ & 0 & $0,0 \%$ & 0 & $0,0 \%$ & 35 & $100,0 \%$ \\
\hline 2 & 3 & $8,6 \%$ & 31 & $88,6 \%$ & 1 & $2,9 \%$ & 0 & $0,0 \%$ & 0 & $0,0 \%$ & 35 & $100,0 \%$ \\
\hline 3 & 3 & $8,6 \%$ & 28 & $80,0 \%$ & 4 & $11,4 \%$ & 0 & $0,0 \%$ & 0 & $0,0 \%$ & 35 & $100,0 \%$ \\
\hline 4 & 11 & $31,4 \%$ & 17 & $48,6 \%$ & 7 & $20,0 \%$ & 0 & $0,0 \%$ & 0 & $0,0 \%$ & 35 & $100,0 \%$ \\
\hline 5 & 3 & $8,6 \%$ & 24 & $68,6 \%$ & 8 & $22,9 \%$ & 0 & $0,0 \%$ & 0 & $0,0 \%$ & 35 & $100,0 \%$ \\
\hline 6 & 9 & $25,7 \%$ & 26 & $74,3 \%$ & 0 & $0,0 \%$ & 0 & $0,0 \%$ & 0 & $0,0 \%$ & 35 & $100,0 \%$ \\
\hline Rata2 & 7 & $20,5 \%$ & 25 & $70,0 \%$ & 3 & $9,5 \%$ & 0 & $0 \%$ & 0 & $0 \%$ & 35 & $100,0 \%$ \\
\hline
\end{tabular}

Sumber: Hasil Penelitian 2020

Dari Tabel 4 di atas dapat dijelaskan bahwa:

1) Jawaban responden pertanyaan No.1: Kuantitas hasil kerja pegawai selama ini dapat dikategorikan baik. Responden yang menjawab sangat setuju sebesar 40,0\%, responden yang menjawab setuju sebesar $60,0 \%$.

2) Jawaban responden pertanyaan No. 2: Kualitas hasil kerja pegawai selama ini dapat dikategorikan baik. Responden yang menjawab sangat setuju sebesar $8,6 \%$, responden yang menjawab setuju sebesar $80,0 \%$, responden yang menjawab kurang setuju sebesar $2,9 \%$.

3) Jawaban responden pertanyaan No. 3: Tingkat efisiensi kerja para pegawai dapat dikategorikan baik. Responden yang menjawab sangat setuju sebesar 8,6\%, responden yang menjawab setuju sebesar $80,0 \%$, responden yang menjawab kurang setuju sebesar $11,4 \%$.

4) Jawaban responden pertanyaan No. 4: Proses pelayanan, administrasi dan informasi pegawai terhadap yang membutuhkan sudah baik. Responden yang menjawab sangat setuju sebesar $31,4 \%$, responden yang menjawab setuju sebesar $48,6 \%$, responden yang menjawab kurang setuju sebesar $20,0 \%$.

5) Jawaban responden pertanyaan No. 5: Ketepatan pegawai dalam melaksanakan suatu pekerjaan sudah baik. Responden yang menjawab sangat setuju sebesar 8,6\%, responden yang menjawab setuju sebesar $68,6 \%$, responden yang menjawab kurang setuju sebesar $22,9 \%$.

6) Jawaban responden pertanyaan No. 6: Pengetahuan pegawai berkaitan dengan pekerjaan utamanya sudah baik. Responden yang menjawab sangat setuju sebesar $25,7 \%$, responden yang menjawab setuju sebesar $74,3 \%$. 
Secara rata-rata dapat dilihat bahwa yang terbesar jawaban responden adalah 70,0\% menyatakan setuju. Dengan demikian dapat diketahui bahwa kinerja pegawai di BPJS Ketenagakerjaan Cabang Binjai adalah baik, sesuai dengan jawaban sebagian besar responden

\section{Pengujian Validitas dan Reliabilitas}

\section{Uji Validitas}

Menurut Sugiono (2004) uji validitas dilakukan dengan menghitung korelasi antar skor masing-masing butir pernyataan dan total skor. Dari tabel $5 \mathrm{~d}$ ibawah ini terlihat bahwa kolerasi semua item untuk budaya organisasi (X), menunjukan hasil yang signifikan yaitu nilai pearson correlation $>0.333$ sehingga dapat disimpulkan semua butir pernyataan budaya organisasi $(\mathrm{X})$ adalah valid.

Tabel 5. Uji Validitas Instrumen Budaya Organisasi (X)

\begin{tabular}{ccccc}
\hline $\begin{array}{c}\text { No. } \\
\text { Item }\end{array}$ & $\begin{array}{c}\text { Corrected item- } \\
\text { total correlation } \\
\left(\mathbf{r}_{\text {hitung })}\right)\end{array}$ & $\begin{array}{c}\left(\mathbf{r}_{\text {tabel })}\right) \\
(\mathbf{n}=\mathbf{3 5}, \boldsymbol{\alpha}=\mathbf{5 \%})\end{array}$ & Kesimpulan & Keterangan \\
\hline Q11 & 0.812 & 0.333 & Valid & Dipakai \\
Q12 & 0.928 & 0.333 & Valid & Dipakai \\
Q13 & 0.928 & 0.333 & Valid & Dipakai \\
Q14 & 0.852 & 0.333 & Valid & Dipakai \\
Q15 & 0.870 & 0.333 & Valid & Dipakai \\
Q16 & 0.928 & 0.333 & Valid & Dipakai
\end{tabular}

Sumber: Hasil Pengolahan SPSS 2020

Selanjutnya dari tabel 6 dibawah ini terlihat bahwa kolerasi semua item untuk karakteristik individu $\left(\mathrm{X}_{2}\right)$, menunjukan hasil yang signifikan yaitu nilai pearson correlation $>0.333$ sehingga dapat disimpulkan semua butir pernyataan Karakteristik Individu $\left(\mathrm{X}_{2}\right)$ adalah valid.

\section{Uji Reliabilitas}

Untuk menguji reliabilitas yang paling sering digunakan kebanyakan peneliti dengan menggunakan Crobach Alpha. Nilai suatu kuesioner dinyatakan reliabel biasanya ditetapkan dengan angka alpha 0.70-0.80 cukup baik untuk tujuan penelitian dasar menurut KaplanSaccuzz (2013:12) atau dapat dengan menggunakan tabel rujukan sebagai berikut:

Tabel 6. Interprestasi Nilai Reliabilitas Instrument Interprestasi

\begin{tabular}{cc}
\hline Interprestasi Nilai Reliabilitas Instrument & Interprestasi \\
\hline $0,80-1,00$ & Tinggi \\
$0,60-0,80$ & Cukup \\
$0,40-0,60$ & Agak rendah \\
$0,20-0,40$ & Rendah \\
$0,00-0,20$ & Sangat rendah
\end{tabular}

Sumber: Kaplan-Saccuzz (2013:12) 
Tabel 7. Uji Reliabilitas X dan Y

\begin{tabular}{lccc}
\hline \multicolumn{1}{c}{ Variabel } & Nilai Alpha & Reliabel/Tidak Reliabel & Keterangan \\
\hline Budaya Organisasi $\left(\mathrm{X}_{1}\right)$ & 0.943 & Reliabel (Tinggi) & Dipakai \\
Kinerja Pegawai (Y) & 0.786 & Reliabel (Cukup) & Dipakai
\end{tabular}

Sumber: Hasil Pengolahan SPSS 2020

\section{Analisis Regresi Linier Berganda}

Analisis regresi linier berganda digunakan untuk mengetahui berapa besar pengaruh budaya organisasi, karakteristik individu dan komunikasi terhadap kinerja pegawai di BPJS Ketenagakerjaan Cabang Binjai. Analisis dilakukan dengan menggunakan bantuan SPSS dengan output sebagai berikut:

Tabel 8. Regresi Linear Berganda

\section{Coefficients ${ }^{\mathbf{a}}$}

Model Unstandardized Coefficients $\begin{aligned} & \text { Standardized } \\ & \text { Coefficients }\end{aligned} \quad \mathrm{t} \quad$ Sig.

B Std. Error Beta

\begin{tabular}{llrrrrr}
\hline & (Constant) & 13.147 & 2.877 & & 4.571 & .000 \\
& Budaya_Org & .314 & .109 & .404 & 2.884 & .007
\end{tabular}

Sumber: Hasil Pengolahan SPSS 2020

\section{Dependent Variable: Y}

Berdasarkan pengolahan data yang terlihat pada tabel output kolom kedua bagian B (Unstandardized Coefficients), diperoleh persamaan regresi linier berganda yaitu:

$$
\begin{aligned}
& y=a+b_{1} x_{1}+b_{2} x_{2}+b_{3} x_{3}+\varepsilon \\
& \mathrm{Y}=13.147+0.314 \mathrm{X}_{1}+0.226 \mathrm{X}_{2}+0.178 \mathrm{X}_{3}+\varepsilon
\end{aligned}
$$

Dengan persamaan regresi linier berganda tersebut dapat dijelaskan bahwa:

1. Nilai konstanta adalah sebesar 13.147 hal ini menyatakan bahwa jika variable budaya organisasi, karakteristik individu dan komunikasi diabaikan, maka nilai kinerja sebesar 13.147.

2. Koefisien regresi untuk variabel budaya organisasi sebesar 0.404 hal ini menunjukkan bahwa setiap kenaikan $1 \%$ faktor budaya organisasi maka akan meningkatkan kinerja pegawai sebesar 40,4\%.

3. Koefisien regresi untuk variabel karakteristik individu sebesar 0.292 hal ini menunjukkan bahwa setiap kenaikan $1 \%$ faktor karakteristik individu maka akan meningkatkan kinerja pegawai sebesar 29,2\%.

4. Koefisien regresi untuk variabel komunikasi sebesar 0.308 hal ini menunjukkan bahwa setiap kenaikan $1 \%$ faktor komunikasi maka akan meningkatkan kinerja pegawai sebesar $30,8 \%$.

5. 


\section{KESIMPULAN}

Dari hasil analisis yang telah dibahas, maka ditarik kesimpulan sebagai berikut Budaya organisasi berpengaruh positif dan signifikan terhadap kinerja pegawai di BPJS Ketenagakerjaan Cabang Binjai dengan $t_{\text {hitung }}>t_{\text {tabel }}(2.884>2.030)$ dan nilai koefisien regresi sebesar 0.404 atau $40.4 \%$. Budaya organisasi berpengaruh signifikan terhadap variabel kinerja pegawai di BPJS Ketenagakerjaan Cabang Binjai.

\section{DAFTAR PUSTAKA}

Fahmi, Irham. 2014. Perilaku Organisasi: Teori, Aplikasi, dan Kasus. Cetakan Kedua. Bandung: CV. Alfabeta. Anggota IKAPI

Robbins, Stephen P dan Timothy A Judge. 2014. Perilaku Organisasi. Jakarta: Salemba Empat.

Sinambela, Lijan Poltak. 2012. Kinerja Pegawai. Yogyakarta: Graha Ilmu

Sugiyono. 2004. Metode penelitian Bisnis. Bandung: Alfabeta.

Tika, H Pabundu. 2012. Budaya Organisasi Dan Peningkatan Kinerja. Jakarta : PT Bumi Aksara. 